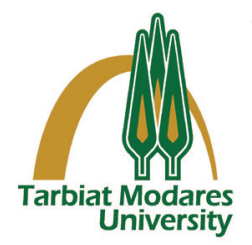

\title{
Community Engagement in the Prevention and Control of Lassa Fever in Africa: A Systematic Review
}

\section{A R T I C L E I N F O}

\section{Article Type}

Review Article

\section{Authors}

Olayinka Ilesanmi, $P h D^{1}$

Ekomobong Oton, $B S c^{1}$

Aanuoluwapo Afolabi, B.Tech ${ }^{*}$
How to cite this article Ilesanmi O., Oton E., Afolabi A. Community Engagement in the Prevention and Control of Lassa Fever in Africa: A Systematic Review: Infection Epidemiology and Microbiology. 2021;7(2): 187-196

${ }^{1-D e p a r t m e n t ~ o f ~ C o m m u n i t y ~}$ Medicine, College of Medicine, University of Ibadan, Oyo State, Nigeria.

\begin{abstract}
A B S T R A C T
Backgrounds: This study aimed to determine community-initiated Lassa fever prevention and control strategies in Africa.

Materials \& Methods: Literature search was performed on four databases, including PubMed, Google Scholar, African Journal OnLine (AJOL), and BioMed Central, using different combinations of the following search terms. A three-stage methodology was employed to conduct the study. At first, related articles were identified using pre-defined key terms, such as Lassa fever, Lassa fever control, Lassa fever prevention, community engagement and Lassa fever, and community participation and Lassa fever. Thereafter, articles were screened to remove duplicates and articles not relevant to the study objectives.

Findings: Community mobilization and sensitization and risk communication were some of the community-directed activities towards Lassa fever prevention and control. Also, stakeholders' advocacy and engagement, rodent control practices, environmental sanitation, and proper food processing and preservation were practiced to prevent Lassa fever. In addition, a referral mechanism from the community to the health facility was constituted through the engagement of community health workers.

Conclusion: Health program managers should strive to provoke coordinated and sustainable community-initiated efforts to improve rodent preventive and control measures. Strategies should be developed and implemented to promote environmental sanitation and restrict cultural practices facilitating contact with rodents or infected persons.
\end{abstract}

Keywords: Lassa, Lassa fever, Lassa virus, Community involvement, Community participation CITATION LINKS

[1] Ogbu 0, Ajuluchukwu E, Uneke CJ. Lassa ... [2] Centre for Disease Control and Prevention. Lassa fever. USA: ... [3] Richmond JK, Baglole DJ. Clinical ... [4] World Health Organization (2018). Lassa fever. Geneva: World ... [5] Lecompte E, Fichet-calvet E, Daffis S, Koulémou K, Sylla O, Kourouma F, et al. Mastomys ... [6] Inegbenebor U, Okosun J, Inegbenebor J. Transactions of the ... [7] Ochei O, Abejegah C, Emmanuel O, Abah SO. Housing ... [8] Ajayi NA, Nwigwe CG, Azuogu BN, Onyire BN, Nwonwu EU, Ogbonnaya LU, et al. Containing ... [9] Iroezindu MO, Unigwe US, Okwara CC, Ozoh GA, Ndu AC, Ohanu ME, et al. ... [10] Federal Ministry of Health. National policy on integrated disease ... [11] Cornish F, Priego-hernandez J, Campbell C, Mburu G, Mclean S. The impact of ... [12] Farnsworth SK, Böse K, Fajobi O, Souza PP, Peniston A, Davidson LL, et al. International ... [13] Kerrigan D, Kennedy CE, Morgan-thomas R, Reza-Paul S, Mwangi P, Win KT, et al. Series HIV and ... [14] Kerrigan DL, Fonner VA, Stromdahl S, Kennedy CE. Community ... [15] O’Mara-Eves A, Brunton G, Mcdaid D, Oliver S, Kavanagh J, Jamal F, et al. Community engagement to ... [16] Questa K, Das M, King R, Everitt M, Rassi C, Cartwright C, et al. Community engagement interventions for ... [17] Amodu SE, Fapohunda SO. Lassa fever and ... [18] Béhanzin L, Adoukonou T, Houeto D, Bokossa C, Agonnoude M. From ... [19] Patassi AA, Landoh DE, Mebiny-Essoh Tchalla A, Halatoko WA, Assane H, Saka B, et al. Emergence of ... [20] Saez AM, Haidara MC, Camara A, Kourouma F, Sage M, Magassouba NF, et al. Rodent ... [21] Woyessa AB, Maximore L, Keller $\mathrm{D}$, Dogba J, Pajibo M, Johnson K, et al. Lesson learned from the investigation and response of Lassa fever outbreak, Margibi ... [22] Ossai EN, Onwe OE, Okeagu NP, Ugwuoru AL, Eze TK, Nwede AS. Knowledge and preventive practices against Lassa fever among heads of ... [23] Adovi AV, Oluwafunmilayo I, Matthew FA, Musah Y, Olusola O, Stephen 00, et al. Lassa fever outbreak in ... [24] Adegoke 00, Ajibola OF, Ogundairo JA. Knowledge, attitude... [25] Tambo E, Adetunde OT, Olalubi OA. Re-emerging... [26] Pettifor A, Lippman SA, Selin AM, Peacock D, Gottert A, Maman S, et al. A cluster randomized-controlled trial of ... [27] Castro MC, Tsuruta A, Kanamori S, Kannady K, Mkude S. Community-based ... [28] Nasir IA, Sani FM, Augusto J, Pereira A. Outbreaks, pathogen containment and ... [29] Tobin EA, Asogun D, Akpede N, Adomeh D, Odia I, Gunther S. Lassa fever ... [30] Gobir A, Ejembi C, Aliyu A, Garba M, Igboanusi C, Usman B, et al. Hygiene ... 


\section{Introduction}

Lassa fever (LF) infection is a zoonotic disease endemic in West African countries [1-2]. Discovered in 1969, LF was named after the Lassa town in Borno State in northeastern Nigeria, where it first appeared among missionary nurses ${ }^{[3]} . \mathrm{LF}$ is a disease manifested as an acute hemorrhagic condition characterized by nausea, febrile illnesses, sore throat, chest and abdominal pain, diarrhea, and coughing ${ }^{[2]}$. Though $80 \%$ of LF cases are asymptomatic, in severe cases, the disease may be accompanied by bleeding tendencies, shock, hearing loss, neck and facial swelling ${ }^{[4]}$. LF infection is estimated to be associated with a global burden of 100,000 to 300,000 infected cases and 5000 deaths annually. The overall case fatality rate is $1-15 \%$ among hospitalized patients with severe conditions ${ }^{[2,4]}$.

LF is caused by Lassa virus belonging to the arenaviradae family, it is present in the urine and feces of infected multimammate rats (Mastomys natalensis) ${ }^{[5]}$. The primary transmission route to human is through direct contact with the mastomys rats or through food and household items contaminated with the urine and feces of infected rats ${ }^{[6-7]}$. The secondary (human-tohuman) transmission route is through direct contact with the blood-secreting organs or other body fluids of infected persons. Nosocomial outbreaks of LF infection are evidence of secondary transmission of LF infection ${ }^{[8-9]}$.

The public health consequences of LF endemicity in West Africa regions necessitate the demand for political will and national policy towards its elimination [1]. For example, in Nigeria, LF is viewed as an epidemic-prone disease that is evolved by an alert threshold of a single suspected case and an epidemic threshold of a single confirmed case ${ }^{[10]}$. This fact has reinforced the commitment of health systems towards its prevention and control through effective measures, including laboratory investigations, clinical care, early detection, surveillance, and proper response to $\mathrm{LF}$ outbreaks.

The World Health Organization highlights preventive measures in communities as one of the key considerations for LF control ${ }^{[4]}$. Studies have shown that community initiatives play a significant role as critical enablers in the control of communicable diseases in low and middle-income countries (LMIC). They could also bridge inequalities in under-resourced health systems while promoting behavioral changes and the delivery of health outcomes to marginalized populations [11-16]. Amodu and Fapohunda (2019) described community engagement as an attractive strategy for preventing $\mathrm{LF}^{[17]}$. Although these interventions are best known as community engagement, the terms such as "community participation", "community mobilization", "community empowerment", and "community sensitization" have also been shown to have similar meaning ${ }^{[15]}$.

Despite the huge benefits provided by community engagement in health interventions, limited evidence exists on the role of community engagement in the prevention and control of LF. The possibility of sustained community participation in addressing the menace of LF in Africa has not yet been ascertained scientifically. Objectives: This study therefore aimed to determine community-initiated LF prevention and control strategies in Africa.

\section{Materials and Methods}

In this systematic review, an online search was conducted on peer-reviewed studies on the concept of Lassa fever and community engagement. The search was carried out on PubMed, Google Scholar, African Journal OnLine (AJOL), and BioMed Central databases. The following search 
terms were used: "Lassa fever prevention and community engagement", "Lassa fever control andcommunity engagement", "Lassa fever prevention and community participation", "Lassa fever control and community participation", "Lassa fever prevention" and "community engagement", "Lassa fever prevention" and "community participation", "Lassa fever control" and "community engagement" as well as "Lassa fever control" and "community participation" with the aid of Boolean operators "AND", "OR", "NOT", and parentheses. Some records were also retrieved using cross-references in published papers. The word "community" was used to describe a group of people living in a particular location and sharing similar characteristics.

Due to the similarities in the contexts, the terms "community empowerment", "community mobilization", "community intervention", and "community sensitization" included in the articles were considered as "community engagement". All articles that reported results on these pre-defined concepts were considered as eligible for this review. However, only articles published in English language were included for ease of understanding by reviewers. All three authors actively participated in the literature search. The systematic review was specifically tailored to address the study objectives. Figure 1 represents the PRISMA flowchart of the article selection process in this systematic review (Figure 1).

A total of 215 articles were identified through the databases search, among which 112 duplicate articles were removed. In addition, 13 review articles, 11 greys, five commentaries, one debate, and four lettersto-the-editor were further excluded. Also, 27 off-topic articles, two articles of non-African settings, and 28 articles on other infectious diseases were removed from the retrieved articles. Overall, eight articles were selected for further evaluation.

\section{Findings}

The selected articles were conducted with various study designs; there were an experimental study, two case reports, and five cross-sectional studies. Also, four studies provided details of coordinated response to LF outbreaks in Sub-Saharan African countries; three studies were focused on preventive practices executed by community individuals, heads of households, and food sellers in Nigerian communities. One study was an experimental study reporting rodentcontrol strategy executed by community members as a preventive measure against LF infection (Table 1).

Ajayi et al. (2013) conducted a crosssectional study providing details of outbreak and response strategies contributing to the control of the LF outbreak in Ebonyi State, Nigeria from January to May 2012. A predominant factor to the success of response strategies was community engagement involving advocacy, communication, mobilization, and shared leadership. Also, a referral mechanism from the community to the health facility was constituted through the engagement of community health workers [8].

Béhanzin et al. was performed a crosssectional study which shows how actions on social determinant of health can contribute to ending the LF pandemic in Tchaourou community in Benin Republic. The study pointed evidence to engaging community members in risk communication and stakeholders mobilization. Stakeholders were saddled with the responsibility of discouraging rats' hunting and consumption, bush burningh, and banning cultural norms of cutting parts of a deceased body for prayers [18].

Patassi et al. (2017) conducted a case report describing the response to the first two cases 
of LF infection in Togo in 2016. Community involvement in control measures included: the use of the sensitization campaigns in schools, mosques, churches, and across borders as well as translation of health information into the local language [19].

The prevention of LF infection by intensifying rodent control practices in the Faranah Region of Upper Guinea was performed in an experimental study by Saez et al. (2018). In this study, communal activities reported for rodents control included the use of rat poison, cats as predators, and dogs for rat trapping or hunting ${ }^{[20] .}$

In a case report, Woyessa et al., (2019) strived to identify the causes of LF to promote LF control and prevention in Margibi county of Liberia during the 2018 LF outbreak. In their study, the involvement of community members in active case finding and tracing of community members' contacts with LF cases was identified as an influential factor in the disease control ${ }^{[21]}$.

Ossai et al. (2020) conducted a crosssectional study to determine the role of knowledge and preventive measures in combating LF among heads of households in Abakaliki, Ebonyi State, Nigeria. The study disclosed that activities such as regular handwashing, good environmental hygiene, proper food storage, and avoidance of consumption of rats were effective measures taken to control LF ${ }^{[22]}$.

In a cross-sectional study detailing response to LF outbreak in Ekiti State, Nigeria, Adovi et al. (2017) highlighted community mobilization and sensitization campaigns as effective measures to control LF. Also, community informants and volunteers were mobilized to carry out contact tracing and active case finding in the community [23]. Adegoke et al. (2017) identified the LF preventive practices among food sellers in major markets in Ibadan city of Oyo State, Nigeria. These practices included the proper covering of food in sacks or air-tight containers and the use of rat repellants and rat poison in food stalls ${ }^{[24]}$.

\section{Discussion}

The endemic state of LF infection in SubSaharan Africa has augmented the need for community members' involvement in the prevention and control of LF. This systematic review across LF-endemic countries presented evidence about the importance of community participation as a component of the disease outbreak response. Community participation is aimed not only at reducing the magnitude of the outbreak, but also at preventing future outbreaks [18].

Despite the lack of sufficient studies to be included in this review, community members were found to play the greatest role in community mobilization towards the prevention and control of LF infection $[8,17$ 19]. This is consistent with the findings of a study describing community mobilization as the collaboration between community stakeholders and members to raise awareness on the health needs, resources, and solutions to meet the challenges in the community [25]. A randomized-controlled study in South Africa demonstrated the role of community mobilization in changing gender norms and reducing HIV risk ${ }^{[26]}$. This array of evidence therefore allows for local ownership and sustainability of LF control and prevention. However, in order to be more effective, it is necessary to incorporate community sensitization campaigns into community mobilization strategy [12, 15].

According to the literature review, it was found that the use of sensitization campaigns could increase community members' awareness of $\operatorname{LF}[8,18-19,23]$. In the reviewed articles, community members were exposed to media sensitization campaigns. The campaign messages were targeted at reducing the risk of exposure to LF infection. For example, Castro 
Table 1) Findings obtained from the literature search in relation to the study objectives

\begin{tabular}{|c|c|c|c|c|c|c|c|c|}
\hline & $\begin{array}{l}\text { Names } \\
\text { of } \\
\text { Author }\end{array}$ & $\begin{array}{l}\text { Name of } \\
\text { Journal }\end{array}$ & Title of Article & $\begin{array}{l}\text { Summarized } \\
\text { Objective }\end{array}$ & $\begin{array}{l}\text { Study } \\
\text { Design }\end{array}$ & $\begin{array}{l}\text { Study } \\
\text { Population }\end{array}$ & Study Area & Outcome \\
\hline 1 & $\begin{array}{l}\text { Ajayi et } \\
\text { al., } 2013^{8}\end{array}$ & $\begin{array}{l}\text { International } \\
\text { Journal of } \\
\text { Infectious } \\
\text { Diseases }\end{array}$ & $\begin{array}{l}\text { Containing a LF } \\
\text { Epidemic in a } \\
\text { Resource-Limited } \\
\text { Setting: Outbreak } \\
\text { Description and } \\
\text { Lessons Learned } \\
\text { from Abakaliki, } \\
\text { Nigeria (January- } \\
\text { March 2012) }\end{array}$ & $\begin{array}{l}\text { To describe } \\
\text { LF outbreak } \\
\text { and response } \\
\text { strategies } \\
\text { in Ebonyi } \\
\text { State, Nigeria } \\
\text { between } \\
\text { January-March } \\
2012\end{array}$ & $\begin{array}{l}\text { Cross- } \\
\text { sectional }\end{array}$ & $\begin{array}{l}\text { Confirmed } \\
\text { and } \\
\text { suspected } \\
\text { cases of LF } \\
\text { in Federal } \\
\text { Teaching } \\
\text { Hospital }\end{array}$ & $\begin{array}{l}\text { Abakaliki, } \\
\text { Ebonyi State, } \\
\text { Nigeria }\end{array}$ & $\begin{array}{l}\text { 1. Public advocacy } \\
\text { was conducted at } \\
\text { the state and district } \\
\text { levels. } \\
\text { 2. Communication } \\
\text { channels of print } \\
\text { and electronic } \\
\text { media were utilized } \\
\text { in disseminating } \\
\text { information on LF } \\
\text { prevention. } \\
\text { 3. Community and } \\
\text { religious leaders } \\
\text { were mobilized to } \\
\text { raise community } \\
\text { members' } \\
\text { awareness on } \\
\text { LF preventive } \\
\text { measures. } \\
4 . \text { Community } \\
\text { health workers were } \\
\text { trained on case } \\
\text { identification and } \\
\text { referral system. }\end{array}$ \\
\hline 2 & $\begin{array}{l}\text { Béhanzin } \\
\text { et al., } \\
2019^{18}\end{array}$ & $\begin{array}{l}\text { Open } \\
\text { Journal of } \\
\text { Epidemiology }\end{array}$ & $\begin{array}{l}\text { From Social } \\
\text { Determinants of } \\
\text { Health Actions } \\
\text { to Fight against } \\
\text { the Lassa Virus } \\
\text { Hemorrhagic } \\
\text { Fever Epidemic } \\
\text { in Tchaourou } \\
\text { Commune in } \\
\text { Benin, } 2018\end{array}$ & $\begin{array}{l}\text { To show } \\
\text { how an } \\
\text { action on the } \\
\text { health social } \\
\text { determinants } \\
\text { could end LF in } \\
\text { Tchaourou }\end{array}$ & $\begin{array}{l}\text { Cross- } \\
\text { sectional }\end{array}$ & $\begin{array}{l}\text { 1. All } \\
\text { cases of LF } \\
\text { occurred in } \\
\text { Tchaourou } \\
\text { community. } \\
\text { 2. All public } \\
\text { health } \\
\text { workers in } \\
\text { Tchaourou } \\
\text { and agents } \\
\text { of zonal } \\
\text { office. } \\
\text { 3. The } \\
\text { general } \\
\text { population } \\
\text { of villages } \\
\text { from which } \\
\text { LF cases } \\
\text { emerged } \\
\text { in the } \\
\text { Tchaourou } \\
\text { community }\end{array}$ & $\begin{array}{l}\text { Tchaourou } \\
\text { Community, } \\
\text { Benin } \\
\text { Republic, } \\
\text { West Africa }\end{array}$ & $\begin{array}{l}\text { 1. Intensified social } \\
\text { mobilization and } \\
\text { risk communication } \\
\text { activities in affected } \\
\text { communities. } \\
2 \text {. Traditional } \\
\text { healers and } \\
\text { community leaders } \\
\text { were sensitized on } \\
\text { LF prevention and } \\
\text { control measures. } \\
\text { These included } \\
\text { termination of } \\
\text { hunting animals } \\
\text { and burning bush, } \\
\text { and cultural norms } \\
\text { of cutting parts of a } \\
\text { deceased body for } \\
\text { prayers. }\end{array}$ \\
\hline 3 & $\begin{array}{l}\text { Patassi } \\
\text { et al., } \\
2017^{19}\end{array}$ & $\begin{array}{l}\text { Case Reports } \\
\text { in Infectious } \\
\text { Diseases }\end{array}$ & $\begin{array}{l}\text { Emergence of } \\
\text { LF Disease in } \\
\text { Northern Togo: } \\
\text { Report of Two } \\
\text { Cases in Oti } \\
\text { District in } 2016\end{array}$ & $\begin{array}{l}\text { This study } \\
\text { reported on the } \\
\text { first two cases } \\
\text { of LF infection } \\
\text { in Togo, and } \\
\text { the response to } \\
\text { these cases. }\end{array}$ & $\begin{array}{l}\text { Case } \\
\text { report }\end{array}$ & $\begin{array}{l}\text { LF cases and } \\
\text { healthcare } \\
\text { workers in } \\
\text { Oti district }\end{array}$ & $\begin{array}{l}\text { Oti district, } \\
\text { Togo }\end{array}$ & $\begin{array}{l}\text { 1. Public } \\
\text { sensitization and } \\
\text { social mobilization } \\
\text { were conducted in } \\
\text { public places. } \\
\text { 2. Health programs } \\
\text { were produced } \\
\text { in the media and } \\
\text { translated into the } \\
\text { local language. } \\
\text { 3. Also, sensitization } \\
\text { sessions were } \\
\text { organized in schools, } \\
\text { mosques, churches, } \\
\text { and across borders. }\end{array}$ \\
\hline
\end{tabular}


Table 1) Continuation

\begin{tabular}{|c|c|c|c|c|c|c|c|c|}
\hline & $\begin{array}{l}\text { Names } \\
\text { of } \\
\text { Author }\end{array}$ & $\begin{array}{l}\text { Name of } \\
\text { Journal }\end{array}$ & $\begin{array}{l}\text { Title of } \\
\text { Article }\end{array}$ & $\begin{array}{l}\text { Summarized } \\
\text { Objective }\end{array}$ & Study Design & $\begin{array}{l}\text { Study } \\
\text { Population }\end{array}$ & $\begin{array}{l}\text { Study } \\
\text { Area }\end{array}$ & Outcome \\
\hline 4 & $\begin{array}{l}\text { Saez } \\
\text { et al., } \\
2018^{20}\end{array}$ & $\begin{array}{l}\text { PLoS Neglected } \\
\text { Topical } \\
\text { Diseases }\end{array}$ & $\begin{array}{l}\text { Rodent Control } \\
\text { to Fight LF: } \\
\text { Evaluation } \\
\text { and Lesson } \\
\text { Learned from a } \\
\text { 4-year Study in } \\
\text { Upper Guinea }\end{array}$ & $\begin{array}{l}\text { This study } \\
\text { aimed to } \\
\text { assess the } \\
\text { feasibility and } \\
\text { acceptability } \\
\text { of community } \\
\text { rodent control } \\
\text { activities }\end{array}$ & Experimental & $\begin{array}{l}\text { Male and } \\
\text { female } \\
\text { community } \\
\text { members }\end{array}$ & $\begin{array}{l}\text { Faranah } \\
\text { region } \\
\text { of upper } \\
\text { Guinea }\end{array}$ & $\begin{array}{l}\text { 1. The use of } \\
\text { food containing } \\
\text { acute poison or } \\
\text { indomethacin, as bait } \\
\text { for killing rats. } \\
2 \text {. The use of cats as } \\
\text { predators for rats in } \\
\text { many houses. } \\
\text { 3. Children } \\
\text { engagement in } \\
\text { rat trapping or rat } \\
\text { hunting with dogs. }\end{array}$ \\
\hline 5 & $\begin{array}{l}\text { Woyessa } \\
\text { et al., } \\
2019^{21}\end{array}$ & $\begin{array}{l}\text { BMC Infectious } \\
\text { Diseases }\end{array}$ & $\begin{array}{l}\text { Lessons } \\
\text { Learned } \\
\text { from the } \\
\text { Investigation } \\
\text { and Response } \\
\text { of LF Outbreak, } \\
\text { Margibi } \\
\text { County, } \\
\text { Liberia, } 2018\end{array}$ & $\begin{array}{l}\text { This study } \\
\text { identified the } \\
\text { cause of LF to } \\
\text { promote LF } \\
\text { control and } \\
\text { prevention }\end{array}$ & Case report & LF cases & $\begin{array}{l}\text { Margibi } \\
\text { County, } \\
\text { Liberia }\end{array}$ & $\begin{array}{l}\text { 1. Community } \\
\text { informants were } \\
\text { engaged in active case } \\
\text { finding, together with } \\
\text { healthcare workers. } \\
\text { 2. Community } \\
\text { members were } \\
\text { trained and deployed } \\
\text { as contact tracers to } \\
\text { identify and follow-up } \\
\text { contacts for symptoms } \\
\text { for } 21 \text { days after } \\
\text { contact with a LF case. }\end{array}$ \\
\hline 6 & $\begin{array}{l}\text { Ossai } \\
\text { et al., } \\
2020^{22}\end{array}$ & $\begin{array}{l}\text { Proceedings } \\
\text { of Singapore } \\
\text { Healthcare }\end{array}$ & $\begin{array}{l}\text { Knowledge } \\
\text { and Preventive } \\
\text { Practices against } \\
\text { LF among Heads } \\
\text { of Households } \\
\text { in Abakaliki } \\
\text { Metropolis, } \\
\text { Southeast } \\
\text { Nigeria: A Cross- } \\
\text { Sectional Study }\end{array}$ & $\begin{array}{l}\text { This study } \\
\text { determined the } \\
\text { knowledge and } \\
\text { prevention of } \\
\text { LF in Abakaliki }\end{array}$ & $\begin{array}{l}\text { Cross- } \\
\text { sectional }\end{array}$ & $\begin{array}{l}\text { Heads of } \\
\text { households }\end{array}$ & $\begin{array}{l}\text { Abakiliki, } \\
\text { Ebonyi } \\
\text { State, } \\
\text { Nigeria }\end{array}$ & $\begin{array}{l}\text { 1. Ensured proper } \\
\text { storage of food. } \\
\text { 2. Ensured good } \\
\text { environmental } \\
\text { hygiene around their } \\
\text { residence } \\
\text { 3. Avoided the } \\
\text { consumption of } \\
\text { rats and foods } \\
\text { contaminated by rats. } \\
\text { 4. Practiced regular } \\
\text { handwashing }\end{array}$ \\
\hline 7 & $\begin{array}{l}\text { Adovi } \\
\text { et al., } \\
2017^{23}\end{array}$ & $\begin{array}{l}\text { Central African } \\
\text { Journal of } \\
\text { Public Health }\end{array}$ & $\begin{array}{l}\text { LF Outbreak in } \\
\text { Southwestern } \\
\text { Nigeria: The } \\
\text { Ekiti State } \\
\text { Response } \\
\text { amidst } \\
\text { Economic } \\
\text { Recession }\end{array}$ & $\begin{array}{l}\text { This study } \\
\text { described the } \\
\text { LF outbreak } \\
\text { response in } \\
\text { Nigeria }\end{array}$ & $\begin{array}{l}\text { Cross- } \\
\text { sectional }\end{array}$ & $\begin{array}{l}\text { Suspected } \\
\text { cases of LF } \\
\text { and their } \\
\text { contacts }\end{array}$ & $\begin{array}{l}\text { Ekiti } \\
\text { State, } \\
\text { Nigeria }\end{array}$ & $\begin{array}{l}\text { A notable control } \\
\text { measure was } \\
\text { community } \\
\text { mobilization and } \\
\text { sensitization } \\
\text { campaign. } \\
\text { Concurrently, } \\
\text { trained volunteers } \\
\text { and community } \\
\text { informants were } \\
\text { mobilized to perform } \\
\text { contact tracing and } \\
\text { active case search at } \\
\text { the community level. }\end{array}$ \\
\hline 8 & $\begin{array}{l}\text { Adegoke } \\
\text { et al., } \\
2017^{23}\end{array}$ & $\begin{array}{l}\text { African } \\
\text { Journal for the } \\
\text { Psychological } \\
\text { Study of Social } \\
\text { Issues }\end{array}$ & $\begin{array}{l}\text { Knowledge, } \\
\text { Attitude and } \\
\text { Practices of } \\
\text { Foodstuff } \\
\text { Sellers on LF in } \\
\text { Major Markets } \\
\text { in Ibadan }\end{array}$ & $\begin{array}{l}\text { This study } \\
\text { assessed the } \\
\text { knowledge, } \\
\text { attitudes, } \\
\text { and practices } \\
\text { of food stuff } \\
\text { sellers on LF } \\
\text { in two major } \\
\text { markets }\end{array}$ & $\begin{array}{l}\text { Cross- } \\
\text { sectional }\end{array}$ & $\begin{array}{l}\text { Market } \\
\text { sellers (both } \\
\text { men and } \\
\text { women) } \\
\text { who sell } \\
\text { raw food } \\
\text { products. }\end{array}$ & $\begin{array}{l}\text { Ibadan, } \\
\text { Oyo } \\
\text { State, } \\
\text { Nigeria }\end{array}$ & $\begin{array}{l}\text { Food sellers practiced } \\
\text { individualistic } \\
\text { approaches to prevent } \\
\text { rat from infesting } \\
\text { their food stalls, using } \\
\text { rat repellents as food } \\
\text { preservatives or rat } \\
\text { poisons to reduce } \\
\text { the rat population. } \\
\text { Also, the food sellers } \\
\text { practiced the acts of } \\
\text { proper storage of food } \\
\text { in sacks or containers } \\
\text { with tight covering. }\end{array}$ \\
\hline
\end{tabular}


et al. (2009) conducted a malaria control study in Tanzania and identified community sensitization as a vital tool for controlling infectious diseases in Africa ${ }^{27]}$. Patassi et al. (2017) in their study noted that sensitization messages were translated and broadcasted in the local language to enhance community engagement ${ }^{[19]}$. In this review, it was found that sensitization activities were conducted among traditional and religious leaders when there was a need to abrogate communal practices, facilitating the occurrence and spread of LF infection, for example, cessation of bush burning prior to new farming seasons. Woyessa et al. (2019) and Adovi et al. (2017) both stated that local leaders were engaged in the shared responsibility of mobilizing community volunteers for case finding and contact tracing ${ }^{[21,23]}$. This supports the fact that community volunteers help improve the access of LF-infected individuals to good health ${ }^{[28]}$. Such activities therefore complement the services provided by community health workers and reduce the incidence of LF infection ${ }^{[28]}$.

This review study findings revealed effective involvement of community members in reducing contact with rats; however, among the reviewed studies, limited studies emphasized the role of community members. For example, Tobin etal. (2015) demonstrated poor acceptance of rodent control strategy in many communities ${ }^{[29]}$. This finding may be due to the relationship between humans and rats, where rats are believed to pose no threat to human well-being. Also, the cultural practice of rat consumption in most LF-endemic communities may ignore the message of rodent elimination as a way of controlling LF ${ }^{\text {[29]. }}$

According to the reviewed that studies, community participation in environmental sanitation practices was found to be effective in reducing rat infestation in the community. Community members exhibit creative personal approaches to environmental hygiene. Such hygienic acts were reported to contribute to a drastic reduction in the prevalence of LF in Kaduna state, Nigeria ${ }^{[30]}$. Also, Ossai et al. (2020) and Adegoke et al. (2017) revealed the effectiveness of individualistic strategies targeted at reducing rodent-to-human contact and human-to-human infection transmission.

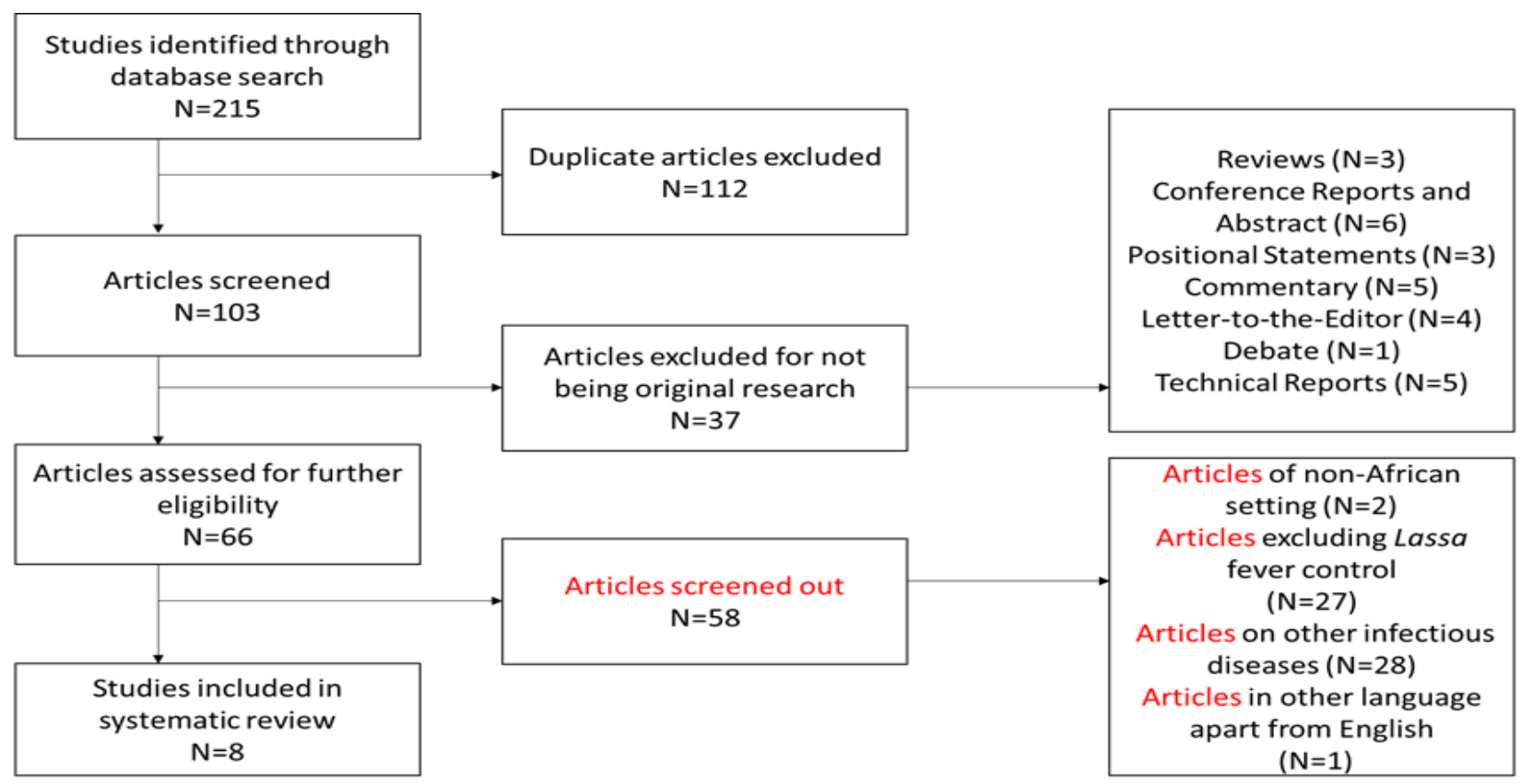

Figure 1) PRISMA flowchart of the article selection process 
Therefore, LF-preventive measures such as regular handwashing as well as proper processing and storage of food should be promoted [22, 24].

\section{Strengths and Limitations}

The use of few databases to retrieve published literature on LF could have limited the results reported in this systematic review. Despite this fall, the study contributes to the existing knowledge regarding the importance of community engagement in disease prevention and control. The endemic nature of LF in Africa, especially West African countries further makes this study very important in the study area.

\section{Conclusion}

Community members are identified to be involved in the implementation of activities aimed at controlling and preventing LF. Examples of these activities include community mobilization and sensitization, shared responsibility of stakeholders, health systems' support of volunteers, rodent control mechanisms, and environmental sanitation. However, there is no evidence about the community-initiated LF preventive and control measures. This may be due to non-inclusion of municipal members in program conceptualization and planning. To empower and enable members to initiate and develop LF prevention and control strategies, it is important to include and activate local engagement protocol as a requirement of program design planning phase. These interventions should be designed to address the predisposing factors of LF infection so that they could be applicable in a specific setting. Communitybased organizations should be engaged to implement interventions to promote communal responsibility, such as coordinated civic labor to promote environmental sanitation and rodent control in public places. Also, there is a need to culturally intensify risk communication to promote behavioral changes among community members and families.

Acknowledgements: None declared by the authors.

Ethical Permission: This study was a review article; hence, no ethical approval was required.

Conflict of Interest: The authors completed the Unified Competing Interest form at www. icmje.org/coi_disclosure.pdf (available upon request from the corresponding author), and declare no conflicts of interest.

Authors' contribution: The study was conceptualized by OSI. Also, OSI, EAO, and AAA participated equally in the review process, manuscript drafting, and reviewing for critical intellectual content. All authors granted approval for the final version of the manuscript. Fundings: None declared by the authors.

Consent to participate: Not applicable.

\section{References}

1. Ogbu O, Ajuluchukwu E, Uneke CJ. Lassa fever in West African sub-region: An overview. J Vect Borne Dis. 2007;44:1-11.

2. Centre for Disease Control and Prevention. Lassa fever. USA: Centre for Disease Control and Prevention; 2014.

3. Richmond JK, Baglole DJ. Clinical review social consequences. BMJ. 2003;327(7426):1271-5.

4. World Health Organization (2018). Lassa fever. Geneva: World Health Organization; 2018.

5. Lecompte E, Fichet-calvet E, Daffis S, Koulémou K, Sylla O, Kourouma F, et al. Mastomys natalensis and Lassa fever, West Africa. Emerg Infect Dis. 2006;12(12):1971-4.

6. Inegbenebor $\mathrm{U}$, Okosun $\mathrm{J}$, Inegbenebor J. Transactions of the royal society of tropical medicine and hygiene prevention of lassa fever in Nigeria. Trans R Soc Trop 
Med Hyg. 2010;104(1):51-4.

7. Ochei O, Abejegah C, Emmanuel O, Abah SO. Housing factors and transmission of Lassa fever in a rural area of southsouth housing factors and transmission of Lassa fever in a rural area of southsouth Nigeria. Gen Health Med Sci. 2014;1(2):15-20.

8. Ajayi NA, Nwigwe CG, Azuogu BN, Onyire BN, Nwonwu EU, Ogbonnaya LU, et al. Containing a Lassa fever epidemic in a resource-limited setting: Outbreak description and lessons learned from Abakaliki, Nigeria. I nt J Infect Dis. 2013;17(11):e1011-6.

9. Iroezindu MO, Unigwe US, Okwara CC, Ozoh GA, Ndu AC, Ohanu ME, et al. Lessons learnt from the management of a case of Lassa fever and follow-up of nosocomial primary contacts in Nigeria during Ebola virus disease outbreak in West Africa. Trop Med Int Health. 2015;20(11):1424-30.

10. Federal Ministry of Health. National policy on integrated disease surveillance and response. Abuja: Federal Ministry of Health; 2005.

11. Cornish F, Priego-hernandez J, Campbell C, Mburu G, Mclean S. The impact of community mobilisation on HIV prevention in middle and low income countries: A systematic review and critique. AIDS Behav. 2014;18(11):211034.

12. Farnsworth SK, Böse K, Fajobi O, Souza PP, Peniston A, Davidson LL, et al. International perspectives community engagement to enhance child survival and early development in low- and middle-income countries: An evidence review. J Health Commun. 201;19(suppl 1):67-88.

13. Kerrigan D, Kennedy CE, Morganthomas R, Reza-Paul S, Mwangi P, Win KT, et al. Series HIV and sex workers 3
A community empowerment approach to the HIV response among sex workers: Effectiveness, challenges, and considerations for implementation and scale-up. Lancet. 2015;385(9963):17285.

14. Kerrigan DL, Fonner VA, Stromdahl S, Kennedy CE. Community empowerment among female sex workers is an effective HIV prevention intervention : A Systematic review of the peer-reviewed evidence from low- and middle-income countries. AIDS Behav.2013;17(6):192640.

15. O'Mara-Eves A, Brunton G, Mcdaid D, Oliver S, Kavanagh J, Jamal F, et al. Community engagement to reduce inequalities in health: A systematic review, meta-analysis, and economic analysis. Public Health Res. 2013;1(4):1548.

16. Questa K, Das M, King R, Everitt M, Rassi C, Cartwright $C$, et al. Community engagement interventions for communicable disease control in low- and lower- middle-income countries: Evidence from a review of systematic reviews. Int J Equity Health. 2020;19(51):1-20.

17. Amodu SE, Fapohunda SO. Lassa fever and the Nigerian experience: A review. Eur J Biol Res. 2019;9(3):155-64.

18. Béhanzin L, Adoukonou T, Houeto D, Bokossa C, Agonnoude M. From social determinants of health actions to fight against the Lassa virus hemorrhagic fever epidemic in Tchaourou commune in Benin. Open J Epidemiol. 2019;9(1):114.

19. Patassi AA, Landoh DE, Mebiny-Essoh Tchalla A, Halatoko WA, Assane H, Saka $B$, et al. Emergence of Lassa fever disease in Northern Togo: Report of two cases in Oti district in 2016. Case Rep Infect Dis. $2017 ; 2017$. 
20. Saez AM, Haidara MC, Camara A, Kourouma F, Sage M, Magassouba NF, et al. Rodent control to fight Lassa fever: Evaluation and lessons learned from a 4-year study in Upper Guinea. PLoS Negl Trop Dis. 2018;12(11):e0006829.

21. Woyessa AB, Maximore L, Keller D, Dogba J, Pajibo M, Johnson $\mathrm{K}$, et al. Lesson learned from the investigation and response of Lassa fever outbreak, Margibi County, Liberia , 2018: case report. BMC Infect Dis. 2019;19(1):1-6.

22. Ossai EN, Onwe OE, Okeagu NP, Ugwuoru AL, Eze TK, Nwede AS. Knowledge and preventive practices against Lassa fever among heads of households in Abakaliki metropolis, Southeast Nigeria: A crosssectional study. Proc Singapore Healthc. 2020;29(2):73-80.

23. Adovi AV, Oluwafunmilayo I, Matthew FA, Musah Y, Olusola 0, Stephen 00, et al. Lassa fever outbreak in Southwestern Nigeria: The Ekiti State response Lassa fever outbreak in Southwestern Nigeria: The Ekiti State response amidst economic recession. CAJPH. 2017;3(2):11-8.

24. Adegoke 00, Ajibola OF, Ogundairo JA. Knowledge, attitude and practices of foodstuff sellers on Lassa fever in major markets in Ibadan. Afr J Psychol Study Soc Issues. 2017;20(2):165-76.

25. Tambo E, Adetunde OT, Olalubi OA. Re-emerging Lassa fever outbreaks in Nigeria: Re-enforcing "One Health" community surveillance and emergency response practice. Infect Dis Poverty. 2018;7(1):1-7.

26. Pettifor A, Lippman SA, Selin AM, Peacock D, Gottert A, Maman S, et al. A cluster randomized-controlled trial of a community mobilization intervention to change gender norms and reduce HIV risk in ral South Africa: Study design and intervention. BMC Public Health. 2015;15(1):1-7.

27. Castro MC, Tsuruta A, Kanamori S, Kannady K, Mkude S. Community-based environmental management for malaria control: evidence from a small-scale intervention in Dar es Salaam. Mal J. 2009;8(1):1-11.

28. Nasir IA, Sani FM, Augusto J, Pereira A. Outbreaks, pathogen containment and laboratory investigations of Lassa fever in Nigeria: How prepared are we ? Int J Trop Dis Health. 2015;10(1):1-10.

29. Tobin EA, Asogun D, Akpede N, Adomeh D, Odia I, Gunther S. Lassa fever in Nigeria: Insights into seroprevalence and risk factors in rural Edo State: A pilot study. J Med Trop. 2015;17(2):51-5.

30. Gobir A, Ejembi C, Aliyu A, Garba M, Igboanusi C, Usman B, et al. Hygiene practices in a Nigerian rural community during Lassa fever epidemic. Saudi J Med Med Sci. 2019; 7(2):121-3. 